\title{
MODELLING THE EFFECT OF WEAVE STRUCTURE AND FABRIC THREAD DENSITY ON MECHANICAL AND COMFORT PROPERTIES OF WOVEN FABRICS
}

\author{
Muhammad Maqsood¹, Yasir Nawab", Khubab Shaker ${ }^{1}$, Muhammad Umair ${ }^{1}$, Munir Ashraf ${ }^{2}$ \\ Danish Mahmood Baitab', Syed Talha Ali Hamdani', Salma Shahid ${ }^{3}$ \\ ${ }^{1}$ Weaving Department, National Textile University, Sheikhupura Road, 37610 Faisalabad, Pakistan, \\ ${ }^{2}$ Textile Processing Department, National Textile University, Sheikhupura Road, 37610 Faisalabad, Pakistan \\ ${ }^{3}$ Department of Chemistry, GC Women University Faisalabad, Madina Town, Faisalabad, Pakistan \\ ${ }^{*}$ Corresponding author: Muhammad Maqsood, E-mail: engr.maqsood@hotmail.com
}

\begin{abstract}
:
The paper investigates the effects of weave structure and fabric thread density on the comfort and mechanical properties of various test fabrics woven from polyester/cotton yarns. Three different weave structures, that is, 1/1 plain, 2/1 twill and 3/1 twill, and three different fabric densities were taken as input variables whereas air permeability, overall moisture management capacity, tensile strength and tear strength of fabrics were taken as response variables and a comparison is made of the effect of weave structure and fabric density on the response variables. The results of fabric samples were analysed in Minitab statistical software. The coefficients of determinations (R-sq values) of the regression equations show a good predictive ability of the developed statistical models. The findings of the study may be helpful in deciding appropriate manufacturing specifications of woven fabrics to attain specific comfort and mechanical properties.
\end{abstract}

\section{Keywords:}

Comfort; mechanical properties; statistical model; weave structure; fabric density

\section{Introduction}

Moisture management is one of the key performance criterion in today's apparel industry, which decides the comfort level of the fabric. Clothing should possess good water vapour as well as liquid moisture transmission property, for providing the thermophysiological clothing comfort [1]. A key cooling mechanism of the human body is sweating and evaporation [2]. Clothing has an important role in keeping the body comfortable by removing sweat. The flow of liquid in fibre assemblies, such as yarn and fabric, happens because of capillary forces [3]. Hydrophilic fibres absorb higher number of water molecules and thus show higher moisture regain at a standard atmospheric condition [4] Liquid transporting and the drying rate of fabrics are two vital factors affecting the physiological comfort of garments. The wicking mechanism of fabrics, their drying behaviour is also an influential parameter of feeling comfortable [5].

Mhetre and Parachuru studied the wicking behaviour in different fabrics and found that it depends on the behaviour of yarns, thread spacing, the rate at which the liquid migrates from longitudinal to transverse thread and back to longitudinal threads [6]. Ren and Ruckman compared the effect of condensation and moisture content in fabric on water vapour transfer rate and concluded that moisture content has greater effect on water vapour transfer rate than condensation [7]. Nyoni stated that wicking was found to increase by increasing yarn tension and reduces as the twist increases but a higher twist level, this trend was seen to be reversed due to spiral wicking. Twist direction was found to have no significant effect on wicking [8]. Raj and Sreenivasan suggested twill weaves produce better thermal insulation due to more thickness as compared to plain weave and twill weave fabrics have better rating as summer wear dress due to improved transport properties [9]. Malik and Hussain concluded that comfort properties are not only associated with the fibres and yarns but also relate with the weave and fabric geometry [10]. Fatahi and Yazdi explained that the air permeability of woven fabrics depends upon the shape and pore size which are related with the structural parameters of the woven fabrics [11]. Nayak studied the comfort properties of suiting polyester fabrics and concluded that the polyester has better mechanical properties but poor thermal properties as compared to cotton fabric moreover cellulosic and polyester blended fabrics give better liquid absorption and transport efficiency [12][13].

Majority of the studies reported in the literature has focused on the investigation of wicking and comfort properties of clothing materials in relation to fibre properties, fabric geometry and finishing treatments. However studies on relationship between weave structure and fabric thread density are still rare as there is paucity of literature on this relationship. The present study was therefore undertaken to investigate the effect of weave structure and fabric density on the comfort and mechanical properties of woven fabrics and to develop statistical models in order to predict these properties of the fabrics.

\section{Experimental}

Nine fabric samples comprising three different weaves, that is, 1/1 plain, 2/1 z-twill and 3/1 z-twill, were produced with three different fabric densities as shown in Table 1. 20/1 Ne polyester/ cotton (PC) combed yarn was used in both warp and weft for all 
fabric samples. Threads per square inch $\left(X_{1}\right)$ and weave float $\left(X_{2}\right)$ were selected as input variables whereas tensile strength, tear strength, air permeability and overall moisture management capacity (OMMC) were taken as response variables. The float size is 1 for $1 / 1$ plain weave, 2 for $2 / 1$ z-twill and 3 for $3 / 1$ z-twill. For threads per square inch, there are equal ends and picks per inch. Fabrics were produced on sample loom (Evergreen $\mathrm{CCl}$ Tech Taiwan). Fabrics were desized with enzyme desizer and then were scoured and bleached.

Comfort properties such as air permeability and OMMC were tested by using ASTM D 737 and AATCC 195 standard test methods, respectively. Mechanical properties such as tensile strength and tear strength were also tested by using ASTM D 5034 and ASTM D 1424 standard test methods, respectively. Air permeability of the fabric samples was evaluated using SDL ATLAS MO21A air permeability tester. The specimen was mounted in the circular specimen holder with sufficient tension to eliminate wrinkle. The specimen was clamped and suction fan was started to pass the air through specimen. The test area of the sample is $50 \mathrm{~cm}^{2}$ and the pressure of the air is kept at $100 \mathrm{~Pa}$. Mean of six values (three from face and three from back) were taken and recorded. Overall moisture management capacity of fabrics was tested by OMMC tester. This test method is for the measurement, evaluation and classification of liquid moisture management properties of textile fabrics. The results obtained by this test method are based on water resistance, water repellency and water absorption characteristics of the fabric structure including the fabric's geometric and internal structure and the wicking characteristics of its fibres and yarns. It works on the principal of electrical resistance by the sensors located on the disc. Fabric is placed in the moisture management tester by keeping the face of fabric downwards. Fabric sample is presented in $8 \mathrm{~cm}$ square shape and sprayed for $20 \mathrm{sec}$ which is allowed to spread for $2 \mathrm{~min}$ then reading are obtained.

\section{Results and discussion}

The statistical analysis of the results was performed using MINITAB 17 statistical software. The regression coefficients and $p$-values of all the terms are given in Table 2.

The terms with p-values less than 0.05 are considered statistically significant with $95 \%$ confidence. A higher value of the coefficient indicates a higher effect of corresponding term and vice versa. A minus (-) sign indicates that the response value increases by decrease in the factor value and vice versa. It is clear from Table 2 that the selected variables that is, fabric thread density $\left(X_{1}\right)$ and weave float $\left(X_{2}\right)$ have significant effect on the resulting tensile strength, tear strength, OMMC and air permeability of the produced samples. The regression equations, comprising the statistically significant terms, are

Table 1. Fabric specifications and test results

\begin{tabular}{|c|c|c|c|c|c|c|c|c|c|c|}
\hline $\begin{array}{l}\text { Sr. } \\
\text { No. }\end{array}$ & $\begin{array}{c}\text { Ends } \\
\text { Per Inch }\end{array}$ & $\begin{array}{c}\text { Picks } \\
\text { Per Inch }\end{array}$ & $\begin{array}{c}\text { Threads } \\
\text { per square } \\
\text { inch }\left(X_{1}\right)\end{array}$ & $\begin{array}{c}\text { Weave } \\
\text { float } \\
\left(X_{2}\right)\end{array}$ & OMMC & $\begin{array}{c}\text { Air } \\
\text { Permeability } \\
(\mathrm{mm} / \mathrm{s})\end{array}$ & $\begin{array}{l}\text { Tensile } \\
\text { Strength } \\
\text { along } \\
\text { warp (N) }\end{array}$ & $\begin{array}{c}\text { Tensile } \\
\text { Strength } \\
\text { along weft } \\
\text { (N) }\end{array}$ & $\begin{array}{c}\text { Tear } \\
\text { Strength } \\
\text { along warp } \\
\text { (N) }\end{array}$ & $\begin{array}{c}\text { Tear } \\
\text { Strength } \\
\text { along } \\
\text { weft }(\mathrm{N})\end{array}$ \\
\hline 1 & 40 & 40 & 80 & $1 .$. & 0.36 & 33.7 & 661.6 & 360.5 & 1872 & 1268 \\
\hline 2 & 40 & 40 & 80 & $2 .$. & 0.41 & 55.5 & 594.5 & 353.4 & 1980 & 1400 \\
\hline 3 & 40 & 40 & 80 & $3 .$. & 0.46 & 78.6 & 558.9 & 319.6 & 2152 & 1678 \\
\hline 4 & 50 & 50 & 100 & $1 .$. & 0.47 & 29.5 & 637.7 & 385.1 & 2280 & 1873 \\
\hline 5 & 50 & 50 & 100 & $2 .$. & 0.48 & 46.3 & 613.9 & 378.1 & 2340 & 2043 \\
\hline 6 & 50 & 50 & 100 & 3.. & 0.49 & 60.9 & 585.9 & 363.7 & 2488 & 2178 \\
\hline 7 & 60 & 60 & 120 & $1 .$. & 0.51 & 23 & 705.2 & 439.5 & 2576 & 2345 \\
\hline 8 & 60 & 60 & 120 & $2 .$. & 0.57 & 40.2 & 660.3 & 421.3 & 2676 & 2566 \\
\hline 9 & 60 & 60 & 120 & $3 .$. & 0.58 & 55.3 & 605.7 & 395.1 & 2733 & 2654 \\
\hline
\end{tabular}

Table 2. Regression coefficients for response variables using coded values of the input variables

\begin{tabular}{|c|c|c|c|c|c|c|c|c|c|c|c|c|}
\hline \multirow{3}{*}{$\begin{array}{c}\text { Terms } \\
\text { Constant }\end{array}$} & \multirow{2}{*}{\multicolumn{2}{|c|}{$\begin{array}{c}\text { Tensile } \\
\text { Strength along } \\
\text { warp }(\mathrm{N})\end{array}$}} & \multirow{2}{*}{\multicolumn{2}{|c|}{$\begin{array}{c}\text { Tensile } \\
\text { Strength along } \\
\text { weft }(\mathrm{N})\end{array}$}} & \multirow{2}{*}{\multicolumn{2}{|c|}{$\begin{array}{c}\text { Tear Strength } \\
\text { along warp (N) }\end{array}$}} & \multicolumn{2}{|c|}{$\begin{array}{l}\text { Tear Strength } \\
\text { along weft }(N)\end{array}$} & \multicolumn{2}{|c|}{ ОМмс } & \multicolumn{2}{|c|}{$\begin{array}{c}\text { Air Permeability } \\
(\mathrm{mm} / \mathrm{s})\end{array}$} \\
\hline & & & & & & & Coeff. & p-value & Coeff. & -value & Coeff. & -value \\
\hline & 624.86 & $0.000^{*}$ & 379.59 & $0.000^{*}$ & 2344.1 & $0.000^{*}$ & 2000.6 & $0.000^{*}$ & 0.4811 & $0.000^{*}$ & 47.000 & $0.000^{*}$ \\
\hline$X_{1}$ & 26.03 & $0.018^{*}$ & 37.07 & $0.000^{*}$ & 330.2 & $0.000^{*}$ & 536.5 & $0.000^{*}$ & 0.0716 & $0.000^{*}$ & -8.217 & $0.000^{*}$ \\
\hline$x_{2}$ & -42.33 & $0.002^{*}$ & -17.78 & $0.004^{*}$ & 107.5 & $0.000^{*}$ & 170.7 & $0.000^{*}$ & 0.0316 & $0.010^{*}$ & 18.100 & $0.000^{*}$ \\
\hline $\mathrm{X}_{1} \mathrm{X}_{2}$ & 0.80 & 0.934 & -0.87 & 0.845 & -30.7 & 0.114 & -25.2 & 0.349 & -0.0075 & 0.469 & -3.15 & $0.046^{*}$ \\
\hline
\end{tabular}


Table 3. Regression equations

\begin{tabular}{|c|c|c|}
\hline Fabric Properties & Regression Equations & R2 (\%) \\
\hline Tensile Strength along warp $(\mathrm{N})$ & $587+1.222 \mathrm{X}_{1}-46.3 \mathrm{X}_{2}+0.040 \mathrm{X}_{1} \times \mathrm{X}_{2}$ & 89.81 \\
\hline Tensile Strength along weft $(\mathrm{N})$ & $221.1+1.941 \mathrm{X}_{1}-13.4 \mathrm{X}_{2}-0.044 \mathrm{X}_{1} \times \mathrm{X}_{2}$ & 96.58 \\
\hline Tear Strength along warp $(\mathrm{N})$ & $171+19.58 \mathrm{X}_{1}+261.3 \mathrm{X}_{2}-1.538 \mathrm{X}_{1} \times \mathrm{X}_{2}$ & 99.29 \\
\hline Tear Strength along weft $(\mathrm{N})$ & $-1276+29.35 \mathrm{X}_{1}+297 \mathrm{X}_{2}-1.26 \mathrm{X}_{1} \times \mathrm{X}_{2}$ & 99.38 \\
\hline OMMC & $-0.016+0.00433 \mathrm{X}_{1}+0.0692 \mathrm{X}_{2}-0.000375 \mathrm{X}_{1} \times \mathrm{X}_{2}$ & 95.29 \\
\hline Air Permeability $(\mathrm{mm} / \mathrm{s})$ & $20.4-0.096 \mathrm{X}_{1}+33.85 \mathrm{X}_{2}-0.1575 \mathrm{X}_{1} \times \mathrm{X}_{2}$ & 98.84 \\
\hline
\end{tabular}

given in Table 3 for all the response variables. The $R^{2}$ values give the percentage of variation in the response variables that can be explained by the factors or terms included in the regression equations.

\subsection{Air Permeability}

Results of air permeability of fabrics are given in Table 1. It can be seen in Table 2 that both the factors are statistically significant for air permeability with $95 \%$ confidence, because their $p$-value is less than 0.05 . Moreover the interaction between two factors, that is, $X_{1} X_{2}$ is also statistically significant because its $p$-value is less than 0.05 . $R^{2}$ (coefficient of determination) for air permeability is given in Table 3 which signifies that $98.84 \%$ change in response can be explained by the terms included in the equation. Surface plot of air permeability versus threads density $\left(X_{1}\right)$ and weave float $\left(X_{2}\right)$ is given in Figure 1 .

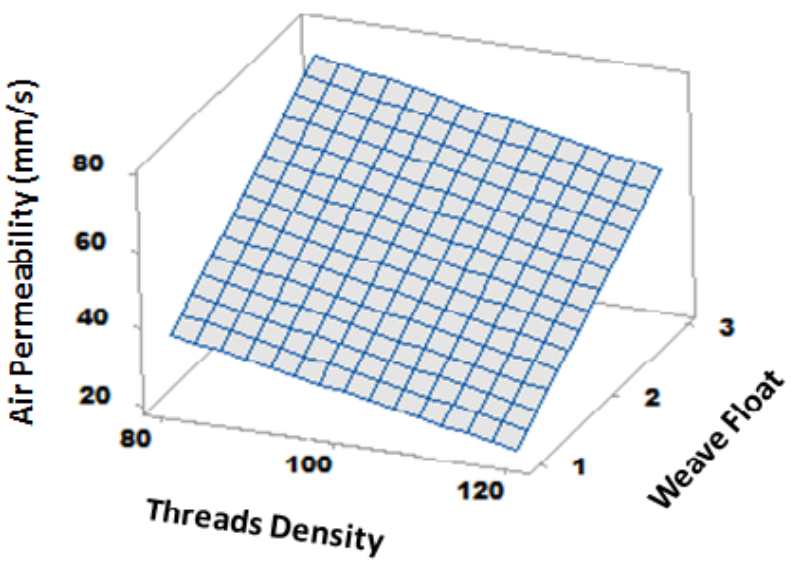

Figure 1. Surface plot of air permeability versus threads density and weave float

It can be observed in Figure 1 that longer weave float and lesser thread density results in greater air permeability of fabrics. It is quite evident from Figure 1 that air permeability of fabrics is lesser when weave float is $1(1 / 1$ plain weave) and greater when weave float is 3 ( $3 / 1$ twill weave). It is due to the fact that plain weave has more compact structure due to greater number of interlacements per unit area as compared to $3 / 1$ twill weave, hence allows less air to pass through the fabric. It is also quite clear from Figure 1 that air permeability of fabrics is lesser when thread density is 120 and greater when thread density is 80 hence thread density has inverse relation with the air permeability of fabrics.

\subsection{OMMC}

Results of OMMC of fabrics are given in Table 1. It can be seen in Table 2 that both the factors, that is, threads density $\left(X_{1}\right)$ and weave float $\left(X_{2}\right)$ are statistically significant for OMMC with $95 \%$ confidence, because their $p$-value is less than 0.05 . However, the interaction between two factors, that is, $X_{1} X_{2}$ is not statistically significant because their $p$-value is greater than 0.05 . $\mathrm{R}^{2}$ for OMMC given in Table 3 signifies that $95.29 \%$ change in response can be explained by the terms included in the equation. Surface plot of OMMC versus threads density and weave float is given in Figure 2.

It can be noticed in Figure 2 that a longer weave float and greater threads density results in higher overall management capacity (OMMC) of fabrics. It is quite evident from Figure 2 that OMMC of fabrics is higher when weave float is 3 (3/1 twill weave) and lower when weave float is 1 (1/1 plain weave). Twill weave fabrics have better wicking property due to improved moisture transport properties as compared to plain weaves [9]. Moreover greater threads density improves fabric's moisture absorbency therefore OMMC of fabrics is higher when thread density is 120 as compared to when it was 80 . So a combination of a weave having longer float and a fabric of greater threads density improves fabrics overall moisture management capacity.

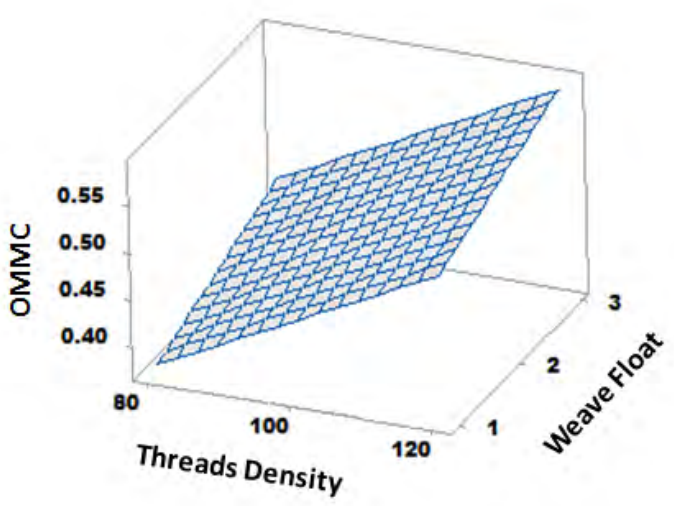

Figure 2. Surface plot of OMMC versus threads density and weave float 


\subsection{Tensile Strength}

Results of tensile strength of fabrics along warp and weft are given in Table 1. It can be seen in Table 2 that both the factors, that is, threads density $\left(X_{1}\right)$ and weave float $\left(X_{2}\right)$ are statistically significant for tensile strength along warp and weft with $95 \%$ confidence, because their $p$-value is less than 0.05 . However the interaction between two factors, that is, $X_{1} X_{2}$ is not statistically significant because their $p$-value is greater than 0.05 . $R^{2}$ for tensile strength along warp and weft is given in Table 3 which signifies that $89.81 \%$ and $96.58 \%$, respectively, change in response can be explained by the terms included in the equation. Surface plots of tensile strength along warp (a) and weft (b) versus threads density and weave float is given in Figure 3.

It can be seen in Figure 3 that a shorter weave float and greater threads density results in a higher tensile strength of fabrics both along warp and weft. It is quite evident from Figure 3 that the tensile strength of fabrics both along warp and weft is higher when weave float is 1 (plain weave) and lower when weave float is 3 (3/1 twill weave). This is due to the fact that plain weave due to greater interlacement points per unit area of fabric makes it difficult to break when breaking load is applied. On the other hand twill weave fabrics were easier to break when breaking load was applied due to a lesser number of interlacement points per unit area, because more interlacement points per unit area makes the fabric more compact and makes it difficult to break.

\subsection{Tear Strength}

Results of tear strength of fabrics along warp and weft are given in Table 1. It can be seen in Table 2 that both the factors, that is, threads density $\left(X_{1}\right)$ and weave float $\left(X_{2}\right)$ are statistically significant for tear strength along warp and weft with $95 \%$ confidence, because their $p$-value is less than 0.05 . However the interaction between two factors, that is, $X_{1} X_{2}$ is not statistically significant because their $p$-value is greater than 0.05 . $R^{2}$ for tear strength along warp and weft is given in Table 3 which signifies that $99.29 \%$ and $99.38 \%$, respectively, change in response can be explained by the terms included in the equation. Surface plots of tear strength along warp (a) and weft (b) versus threads density and weave float are given in Figure 4.

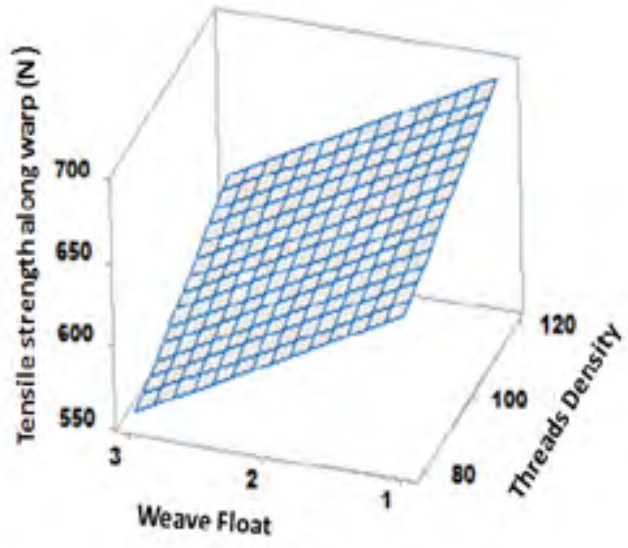

(a)

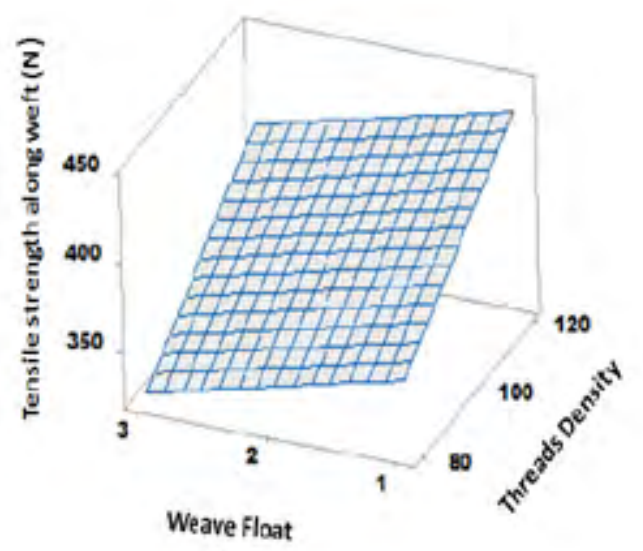

(b)

Figure 3. Surface plots of tensile strength along warp (a) and weft (b) versus threads density and weave float

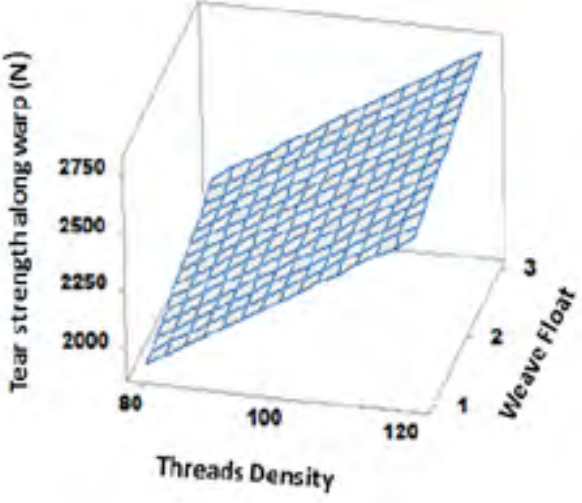

(a)

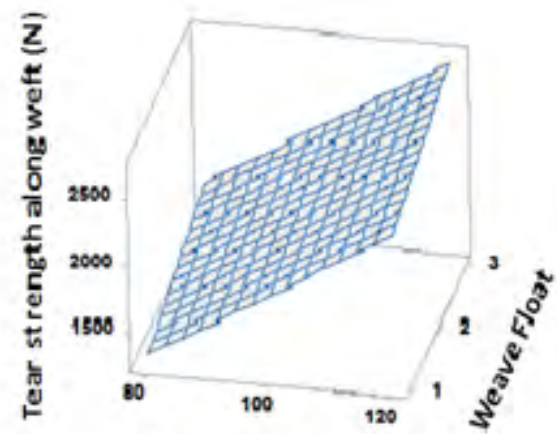

Threads Density

(b)

Figure 4. Surface plots of tear strength along warp (a) and weft (b) versus threads density and weave float 
It can be observed in Figure 4 that longer weave float and greater threads density results in higher tear strength of fabrics both along warp and weft. It is quite evident from Figure 4 that the tear strength of fabrics both along warp and weft is higher when weave float is 3 ( $3 / 1$ twill weave) and lower when weave float is 1 (plain weave). This is due to the fact that twill weave due to lesser interlacement points per unit area of fabric makes it difficult to tear when load is applied due to yarn slippage. On the other hand plain weave fabrics were easier to tear when load was applied due to greater number of interlacement points per unit area, because more interlacement points per unit area do not allows the yarn to slip and makes it easier to tear.

\section{CONCLUSIONS}

In this study, different mechanical and comfort related properties of fabrics produced from different weave structures and fabric densities were compared. Fabrics produced by different weaves not only differ from one another with respect to their structure but also possess different features related to mechanical and comfort properties. It is concluded that fabrics produced from plain weave is less permeable to air as compared to $3 / 1$ twill weave. Weave float plays an important role in air permeability of fabrics as air permeability rises with increasing float of yarn. Moreover threads density has inverse relation with air permeability of fabrics; greater the threads density lesser will be the air permeability of fabrics. Overall moisture management capacity of fabrics produced from twill fabrics is greater than fabrics produced from plain weave because twill weave fabrics have better wicking property due to improved moisture transport properties as compared to plain weaves. The value of OMMC was higher at higher threads density and lower at lower threads density. Tensile strength of fabrics produced from plain weave was greater than fabrics produced from twill weaves due to greater number of interlacements per unit area. Tear strength of fabrics produced from twill weave was greater than fabrics produced from plain weaves due to greater yarn slippage. Statistical models for predicting the comfort and mechanical properties of different woven fabrics were developed. The coefficients of determinations (R-sq values) of the regression equations showed a good predictive ability of the developed statistical models. The findings of the study may be helpful in deciding appropriate manufacturing specifications of woven fabrics to attain specific comfort and mechanical properties.

\section{References}

[1] Chinta, S. K. (2013). Significance of Moisture Management for High Performance Textile Fabrics. Int. J. Innov. Res. Sci. Eng. Technol. 2 (3), 814-819.

[2] Hu, J. (2005). Moisture Management Tester: A Method to Characterize Fabric Liquid Moisture Management Properties. Text. Res. J. 75 (1), 57-62.

[3] Babu, R., Ramakrishnan, Subramanian \& Kantha, L. (2012). Analysis of Fabrics Structure on the Character of Wicking. J. Eng. Fiber. Fabr. 7 (3), 28-33.

[4] Das, B., Das, A., Kothari, V., Fanguiero, R. \& Araujo, M. D. (2009). Moisture Flow through Blended Fabrics - Effect of Hydrophilicity. J. Eng. Fiber. Fabr. 4 (4), 20-28.

[5] Duru, S. C. \& Candan, C. (2012). Effect of Repeated Laundering on Wicking and Drying Properties of Fabrics of Seamless Garments. Text. Res. J. 83 (6), 591-605.

[6] Parachuru, S. (2010). The Effect of Fabric Structure and Yarn-to-Yarn Liquid Migration on Liquid Transport in Fabrics. J. Text. Inst. 101 (7), 621-626.

[7] Ruckman, Y. (2003). Water Vapour Transfer in Wet Waterproof Breathable Fabrics. J. Ind. Text. 32 (3), 165175.

[8] Nyoni, A. B. (2006). Wicking Mechanisms in Yarns-The Key to Fabric Wicking Performance. J. Text. Inst. 97 (2), 119-128.

[9] Sreenivasan, S. (2009). Total Wear Comfort Index as an Objective Parameter for Characterization of overall Wear ability of Cotton Fabrics. J. Eng. Fiber. Fabr. 4 (4), 35-40.

[10] Malik, Z. A. (2011). Development of Model to Predict Tensile Strength of Cotton Woven Fabrics. J. Eng. Fiber Fabr. 6 (4), 41-45.

[11] Fatahi, I. (2010). Assessment of Relationship between Air Permeability of Woven Fabrics and its Mechanical Properties. Fibers Text. East. Eur. 18 (6), 68-71.

[12] Nayak, R. K. (2009). Comfort Properties of Suiting Fabrics. Indian J. Fibers Text. Res. 34 (1), 122-128.

[13] Maqsood, M., Hussain, T., Malik, M. H., Nawab Y. (2015). Modeling the effect of elastane linear density, fabric thread density and weave float on the stretch, recovery and compression properties of bi-stretch woven fabrics for compression garments. J. Text. Inst. 